\title{
Semiosphere and/as the research object of semiotics of culture
}

\author{
Peeter Torop \\ Dept. of Semiotics, University of Tartu \\ Tiigi 78, 50410 Tartu, Estonia \\ e-mail: peeter.torop@ut.ee
}

\begin{abstract}
Since 1984 when J. Lotman's article "On semiosphere" was published, this concept has been moving from one terminological field to another. In the disciplinary terminological field of the Tartu-Moscow School semiotics of culture, 'semiosphere' is connected with terms 'language - secondary modelling system - text - culture'. From interdisciplinary terminological fields, the associations either with biosphere and noosphere, or with logosphere, are more important. As a metadisciplinary concept, semiosphere belongs to the methodology of culture studies and is associated with the concepts of holism and the part and the whole. In this context, semiosphere marks the complementarity of disciplines studying culture, the movement towards the creation of general culture studies and "understanding methodology". On the background of the contemporary trends of science it has to be remembered that semiosphere is simultaneously an object- and a metaconcept. The dynamism of culture as a research object forces science to search for new description languages but the new description languages in turn influence the cultural dynamics as they offer new possibilities for selfdescription. Often, however, from a historical perspective, a new description language is nothing but a methodological translation. Thus also the term semiosphere joins together several concepts that are related to semiotics of culture and that have gained new relevance on the background of the culture's developmental dynamics. The concept of semiosphere brings semiotics of culture again into contact with its history, as it also brings applicational cultural analysis into contact with the history of culture and with the newest phenomena in culture. These contacts determine the place of the semiotics of culture among the sciences studying culture. ${ }^{1}$
\end{abstract}

The article is based on the presentation at the First International Meeting for the Study of the Semiosphere, organized by Irene Machado and her colleagues in São Paulo, Brazil, August 22-27, 2005. 
Disciplinary logic demands that culture be declared the research object of semiotics of culture. But only a few years ago, in the epilogue to his study "The outlines of the prehistory and history of semiotics", Vyatcheslav Vs. Ivanov, one of the founders of semiotics of culture and of the Tartu-Moscow School of Semiotics, wrote:

The task of semiotics is to describe the semiosphere without which the noosphere is inconceivable. Semiotics has to help us in orienting in history. The joint effort of all those who have been active in this science or the whole cycle of sciences must contribute to the ultimate future establishment of semiotics. (Ivanov 1998: 792)

Ivanov's statement relies already clearly on interdisciplinary logic as the term "semiosphere" is here placed between biosphere and noosphere. It follows from this logic that the description of semiosphere by semiotics helps us to orient in history. But the term "history" is a very complicated concept for the scientists of the TartuMoscow School.

In the context of semiosphere, the interest of Juri Lotman as a literary and cultural historian in unmaterialized possibilities of historical choices is important. He had an extraordinary interest in imagining the consequences to which a different choice of development strategies could have led during pivotal moments, in the situation of cultural explosion. He speaks about this in his last book Culture and Explosion (published in 1992). At the request of Spanish colleagues, I had a discussion with Juri Lotman in the same year as this book was published. I will quote a passage from Lotman's talk:

The fate of people, history, accomplishments of science is unpredictable. [...] A chance, an accident is not really so accidental, I would say. A chance is so diffused, leaves such a wide range of choices that many things can find their place in there. But chance is not predictable. I think that if, among new ideas, there is something that we have now in reality, one of them - and I think the most important of them - is the idea of historical, scientific, and of yet some other kind of unpredictability. Unpredictability as the object of science. By the way, unpredictability [...] whose mechanism is one of the most important objects of science, introduces into science in a totally new manner the component of art. [...] Art has always been oriented towards unpredictability. To my mind, at the moment something most interesting is happening: it is as if science is becoming aesthetisized. [...] Art is a totally different way of thinking, a different system of modelling the world. Essentially it is the creation of a different world, a parallel world to our world. It is thought that 
we can live in a world that is based on the model of science, or that we can live in a world that is based on the model of art. In fact, however, we live in a world that is based on the conflictual unity of these two models. From here follow also the different levels of predictability and different meanings of unpredictability. (Lotman, in Torop 2000: 13-14)

The logic of this argument is close to our contemporary transdisciplinary thinking. But at the end of discussion Lotman presented a rhetorical question:

What in fact is this enormous amount of people who now live on this planet and will maybe live here also in the future? Is it a conglomeration of individuals who live only in order to take over from each other territory and the right to live? Or is this conglomeration of individuals one method of description and each individual by himself or herself another method of description? Thus no method of description rules out another method of description. It is as if in their reciprocal tension they create a third viewpoint. (Lotman, in Torop 2000: 14-15)

The formulation of this third viewpoint would in fact mean that semiotics is given the status of metadiscipline.

Since the year 1984 when J. Lotman's article "On semiosphere" was published, this concept has been moving from one terminological field to another. In the disciplinary terminological field of the TartuMoscow School semiotics of culture, "semiosphere" is connected with terms "language - secondary modelling system - text - culture". From interdisciplinary terminological fields, the association, on the one hand, with biosphere and noosphere, and on the other hand, with logosphere, is perhaps more important. As a metadisciplinary concept, semiosphere belongs to the methodology of culture studies and is associated with the concepts of holism and the part and the whole. And as a transdisciplinary concept, "semiosphere" is very close to the concept of symbol in symbolism: symbol as an indefinable term is suitable for conveying the cognition of the incognizable, and at the same time symbol can have an enormous semantic volume as a reduced myth. In this context, semiosphere marks the complementarity of disciplines studying culture, the movement towards the creation of general culture studies and "understanding methodology".

For example, when we observe the scholarly reception of the concept of semiosphere, we can notice the emergence of some dominants. The first dominant is related to semiosphere as a universal 
research level. For instance, Irene Portis-Winner in her last book remarks that Lotman's concept of semiosphere creates a perspective of holistic analysis: "Lotman's concept of the semiosphere subsumes all aspects of the semiotics of culture, all the heterogeneous semiotic systems or "languages" that are constantly changing and that in an abstract sense, have some unifying qualities" (Portis-Winner 2002: 63; cf. also Portis-Winner 1999). Edna Andrews, again, argues that the concept of semiosphere is helpful in better understanding semiosis: "Lotman's extensive work on the semiosphere and the semiotics of communication provide some invaluable concepts and categories that offer insights into the structural principles of semiosis" (Andrews 1999: 8). And in Neil Cornwell's opinion, the quality of the semiosphere to bind diachrony and synchrony, organize memory, transform systems turns it into a very functional mechanism that has been connected even with the Jungian term of collective unconscious (Cornwell 1992: 166).

From collective unconscious it is convenient to proceed to the next dominant, dynamism. Bogusław Żyłko stresses, from the perspective of Lotman's evolution, that the concept of semiosphere signifies transfer from static to dynamic analysis, and the basis of this transfer is understanding the relationship between holism and heterogeneity:

The shift, from the conception of culture as a bundle of primary and secondary modelling systems to the notion of semiosphere, is also a shift from static to dynamic thinking. If we took the former approach, culture would resemble a motionless unit made up of semiotic systems; whereas if we follow the semiospheric approach, culture takes the shape of a heterogeneous whole bustling with multiple rhythms of development and transient dominants. (Żyłko 2001: 400)

Dynamism is stressed also by Floyd Merrell in his comparison of Peirce and Lotman and treatment of biosemiosphere: "Cultures are processes, never products [...]" (Merrell 2001: 400).

I brought out these two dominants in the reception of semiosphere in order to emphasize one of Lotman's methodological principles, on which also his own treatment of semiosphere is based. This is the principle of dialogism. Usually the term "dialogue" is associated with the name of Mikhail Bakhtin, and Lotman's treatment certainly has its connections to Bakhtin's approach. The treatise published under the 
name of Valentin Voloshinov Marxism and the Philosophy of Language suggests that

any element of an utterance that forwards a thought and is being foregrounded, or even a full utterance is translated by us into corresponding context that is different and active. Any understanding is dialogic. Understanding is contrasted to utterance as a speaker's words are contrasted to those of another speaker in a dialogue. Understanding is looking for a counterword to the word of a speaker. Only understanding of a foreign word seeks for "a similar" word in the native language. (Bakhtin 2000: 436)

Several scholarly works have been dedicated to the comparison of $\mathrm{M}$. Bakhtin's and J. Lotman's dialogisms (Shukman, Lachmann, Danow, Bonafin), but the simultaneity of the dual understanding has not been stressed much. In essence, this is a situation in which understanding is a process that on the one hand creates differences (word and the counterword), and, on the other hand, similarities (word and its translation). And if the dialogism of understanding is borne in mind, we can in principle talk about two types of dialogue (cf. also Torop 2002: 599-602).

Furthermore, in Lotman's opinion, in order to understand dialogue, it is not enough to understand the language that is used in the dialogue. In his article "On Semiosphere" he wrote:

Consciousness is impossible without communication. In this sense it can be said that dialogue precedes language and generates the language. The idea of semiosphere is based exactly on this: the ensemble of semiotic formations precedes (not heuristically, but functionally) a single isolated language and is a precondition for its existence. Without semiosphere a language not only does not work, but does not even exist. (Lotman 1984: 16)

In the next stage of discussion on semiosphere, in his book "Universe of the Mind" published in 1990, Lotman emphasized that the dialogic situation has to be understood before dialogue: “...the need for dialogue, the dialogic situation, precedes both real dialogue and even the existence of a language in which to conduct it: the semiotic situation precedes the instruments of semiosis" (Lotman 1990: 143144). Thus dialogue becomes not only a term closely related to semiosphere, but it becomes one of its ontological characteristics. The concept of dialogical model of culture appeared in Lotman's works in 
1983 and the discussion on semiosphere develops this model first of all on the level of dynamics between the part and the whole:

Since all the levels of the semiosphere - ranging from a human individual or an individual text to global semiotic unities - are all like semiospheres inserted into each other, then each and one of them is both a participant in the dialogue (a part of the semiosphere) as well as the space of the dialogue (an entire semiosphere). (Lotman 1984: 22)

The understanding of dialogue as an ontological characteristic of semiosphere in turn means that the outer and inner borders of semiosphere are seen as bilingual. Borders separate and thus create identities, but borders also connect and construe these identities by juxtaposing the own and the alien. Therefore for Lotman the most important feature of the borders of semiosphere is their role as translation mechanisms. But also human consciousness is related to the same mechanisms since in determining one's identity, a person needs first to describe it to himself or herself. Translation mechanisms form the basis also for this thinking activity. And thus Lotman reaches the conclusion "that the elementary act of thinking is translation" and "the elementary mechanism of translation is dialogue"(Lotman 1990: 143).

The dialogism of semiosphere lends the concept of semiosphere also an important dimension pertaining to the history of science. In 1992 Lotman wrote in the foreword of Sign Systems Studies vol. 25 that was the last appearing in his lifetime:

During the past decades semiotics has changed. One achievement on its hard path was unification with history. The cognition of history became semiotic, but semiotic thinking obtained historic traits. [...] Semiotic approach tries to avoid the conditional stopping of the historical process. (Lotman 1992: 3)

Lotman also concludes that "each generation has a language for describing yesterday and principally lacks a language for tomorrow" (Lotman 1992: 4).

Speaking about semiosphere on the background of the contemporary trends of science it has to be remembered that semiosphere is simultaneously an object- and a meta-concept. Semiosphere is what is being studied in or as culture, and semiosphere is the means that is used in studying culture. A phrase semiosphere is studied by means of 
semiosphere is not a paradox but points to the dialogue between the research object and its description language. The dynamism of culture as a research object forces science to search for new description languages but the new description languages in turn influence the cultural dynamics as they offer new possibilities for self-description. Often, however, from a historical perspective, a new description language is nothing but a methodological translation. Thus also the term semiosphere joins together several concepts that are related to semiotics of culture and that have gained new relevance on the background of the culture's developmental dynamics.

The first who deserves rereading is one of the leading figures of Russian Formalism Yurij Tynianov. In his article "Literary fact" of 1924 he wrote: "Literary fact is heterogeneous, and in this sense literature is an incessantly evolutioning order" (Tynianov 1977: 270). The question of literary order or system is for Tynianov inseparable from the question of function:

A literary system is first of all a system of the functions of the literary order which are in continual interrelationship with other orders. Systems change in their composition, but the differentiation of human activities remains. The evolution of literature, as of any other cultural system, does not coincide either in tempo or in character with the systems with which it is interrelated. This is owing to the specificity of the material with which it is concerned. The evolution of the structural function occurs rapidly; the evolution of the literary function occurs over epochs; and the evolution of the functions of a whole literary system in relation to neighbouring systems occurs over centuries. (Tynianov 1977: 277)

In Tynianov's system, we can observe the relatedness of literary order to other orders - with the order of everyday life, the order of culture, social order. Everyday life is correlated with literary order in its verbal aspect, and thus, literature has a verbal function in relation to everyday life. An author's attitude towards the elements of his text expresses structural function, and the same text as a literary work has literary function in its relations to the literary order. The return influence of literature on everyday life, again, expresses social function. The study of literary evolution presupposes the investigation of connections first of all between the closest neighbouring orders or systems, and the logical path leads from the structural to the literary function, from the literary to the verbal function. This follows from the position that "evolution is the change in interrelationships between the elements of 
a system - between functions and formal elements" (Tynianov 1977: 281; cf. also Torop 1995-1996; 2003: 328-330).

The next author belonging to the history of semiosphere is Roman Jakobson who in his article "Metalanguage as a linguistic problem" published in 1956 wrote: "Language must be investigated in all the variety of its functions" (Jakobson 1985: 113). With regard to the six factors of his communication model and their functions he wrote: "The diversity lies not in a monopoly of some one of these several functions but in their different hierarchical order" (Jakobson 1985: 113).

With regard to the rapid development of the culture's technological environment, I suggest that the hierarchical principle is the basis for Jakobson's approach both to translation as well as perception processes. His interlinguistic, intralinguistic and intersemiotic types of translation can be regarded individually but also as an inner dynamic hierarchy of a single translation process and, partly, of any communication process. The situation is the same when R. Jakobson stresses the semiotic value of all five senses in the human society: "All five external senses carry semiotic functions in human society" (Jakobson 1971: 701). Foreseeing the increase in the varieties of textual ontologies and problems of understanding, R. Jakobson stresses the importance of distinguishing between homogeneous messages, i.e. those based on a single sign system, and syncretic messages, i.e. those based on the combination of several sign systems: "The study of communication must distinguish between homogeneous messages which use a single semiotic system and syncretic messages based on a combination or merger of different sign patterns" (Jakobson 1971: 705).

Another semiospheric scientist is Mikhail Bakhtin of whose works I would like to mention in the present context the theory of chronotope even though this work was left unfinished. Nevertheless, it is still possible to reconstruct Bakhtin's general understanding of a literary work as a chronotopical hierarchy (Bakhtin 1979: 338). On the horizontal plane this refers to the levels of topographic chronotope or homophony, psychological chronotope or polyphony, and metaphysical chronotope or heterophony. But on all these levels we can also speak of the binarity of the own and the alien (cf. Torop 1997), which is the basis for the so-called small chronotopes, such as road, bridge, stairs, and so forth. In Bakhtin's view, without understanding 
chronotopicality, it is impossible to understand artistic worlds (Bakhtin 1975: 406).

Thus there are three research strategies in front of us, which prepare the ground for the emergence of the concept of semiosphere: Tynianov and the hierarchical treatment of the evolutionary process, Jakobson and the hierarchical treatment of communication process, and Bakhtin and the treatment of text as a chronotopical hierarchy.

Theses on the Semiotic Study of Cultures [1973], the programmatic work of the Tartu-Moscow School, defines semiotics of culture as a science investigating the functional correlation of different sign systems. This approach entails also the recognition of the hierarchy of sign systems:

In defining culture as a certain secondary language, we introduce the concept of a "culture text", a text in this secondary language. So long as some natural language is a part of the language of culture, there arises the question of the relationship between the text in the natural language and the verbal text of culture. (Theses 1998: 43)

We could add here another aspect related to the logic of possible worlds: "The place of the text in the textual space is defined as the sum total of potential texts" (Theses 1998: 45).

Until then, when speaking of text, Lotman had emphasized the importance of the beginning and the end, or the frame. Therefore for him, text was a delimited whole and the possibility of delimiting, either natural or artificial, made it possible to speak about levels of material, the coherence and hierarchy of levels. When the material was not natural language but film language, he tried to describe the system of distinctive features and to analyse the text on the basis of markedness-unmarkedness. A fundamental turn took place in 1981. In his article "Cultural Semiotics and the Notion of Text" Lotman replaces the notion of deciphering or decoding the text with the term of communication and creates, by describing circulation of texts in culture and relations between the text and the reader, a typology of different, although complementary processes: (1) communication of the addresser and the addressee, (2) communication between the audience and cultural tradition, (3) communication of the reader with $\mathrm{him} /$ herself, (4) communication of the reader with the text, (5) communication between the text and cultural tradition (Lotman 2002: 88 ). The usage of the term communication in textual analysis meant, 
in fact, a semiospherical turn already before the concept was born. The same way as it is possible to understand texts in various ways, it is also possible to analyse this understanding in several ways.

When Lotman's approach to text became parametric, combining different possibilities of analysis, there emerged a need for a unity of a higher order that would join together the individual and the general, the part and the whole, description and self-description. The juxtaposition, in textual analysis, of a delimited whole and a communicating whole created the wish to keep system and process apart, similarly to what L. Hjelmslev did. In 1978 Lotman wrote an article "The phenomenon of culture" where he created a typology distinguishing between statics and dynamics. The basis for the typology is the distinction of the static and dynamic aspects of cultural languages. From the static aspect cultural languages divide into the discrete and the continual (iconic-spatial), and for Juri Lotman this forms the semiotic primordial dualism. In discrete languages sign comes first and meanings are created through the meanings of signs. In continual languages text comes first and meaning emerges through holistic text that integrates even the most heterogeneous elements. These are the two languages between which it is difficult to create translatability.

In dynamism the simultaneity of the two processes in culture is important. On the one hand, in different fields of culture, specialisation of cultural languages takes place as a result of autocommunication and identity searches. On the other hand, on the level of culture as a whole there emerges integration of cultural languages as a possibility of self-communication and self-understanding. Yet the dynamism of integration is revealed in the simultaneity of the two processes. On the one hand, self-descriptions and alongside with them also meta-descriptions or descriptions from the position of culture as a whole are being created in different parts of culture. This is integration through autonomies. On the other hand, cultural languages diffuse and become creolised due to the communication between different parts of culture. Creolisation is a feature of dynamism and an intermediary stage at reaching a new autonomy or pure (self)description.

As a result of descriptive processes this allows us to talk about cultural self-models. Cultural self-description as a process can be viewed as proceeding in three directions. Culture's self-model is the result of the first, and its goal is maximum similarity to the actually existing culture. As a second result there emerge cultural self-models 
that differ from ordinary cultural practice and have been designed for changing that practice. Thirdly, there are also self-models that exist as an ideal cultural self-consciousness separately from culture and are not oriented toward it (Lotman 2000: 568-580). By this Lotman does not exclude conflict between culture and its self-models. But the creation of self-models reflects the creativity of culture. In 1980s Juri Lotman described creativity, relying on Ilya Prigogine. The article "Culture as a subject and object for itself" maintains that:

The main question of semiotics of culture is the problem of meaning generation. What we shall call meaning generation is the ability both of culture as a whole and of its parts to put out, in the "output", nontrivial new texts. New texts are the texts that emerge as results of irreversible processes (in Ilya Prigogine's sense), i.e. texts that are unpredictable to a certain degree. (Lotman 2000: 640)

Semiosphere is a concept that allows semiotics of culture to reach a new understanding of holism, a holistic analysis of dynamic processes. In semiotics of culture, the term semiosphere converges all that which recently in sciences studying culture converges into semiotics - a wish for finding a description language that could be translated into and that could unify different disciplinary and interdisciplinary languages. In elaborating general principles of cultural analysis in the interests of an understanding methodology, science needs to search for possibilities to interpret as diverse and nontrivial cultural phenomena and texts as possible and to promote cultural self-descriptions. At the same time, from the historical perspective, the metalinguistic and conceptual heterogeneity of our contemporary science is much more homogeneous.

Therefore, in conclusion it has to be said that the concept of semiosphere brings semiotics of culture again into contact with its history, as it also brings applicational cultural analysis into contact with the history of culture and with the newest phenomena in culture. The science of signs comes into contact with the art of signs. These contacts determine the place of the semiotics of culture among the sciences studying culture. And it is not paradoxical that semiosphere studies semiosphere and culture studies culture. This is so because all this takes place within one single semiosphere of human culture and each attempt to describe culture from any scientific position proves, 
on a different level, to be a self-description of culture. By creating treatments of culture, we also can be part of culture's creativity. ${ }^{2}$

\section{References}

Bakhtin, Mikhail M. 1975 = Бахтин, Михаил. Вопросы литературы $u$ эстетики. Москва: Художественная литература.

- 1979 = Бахтин, Михаил. Эстетика словесного творчества. Москва: Искусство.

— 2000 = Бахтин, Михаил М. Фрейдизм. Формальный метод в литературоведении. Марксизм и философия языка. Статьи. Москва: Лабиринт.

Bonafin, Massimo 1997. Typology of culture and carnival: Note on the models of Bachtin and Lotman. Russian Literature 41(3): 255-268.

Cornwell, Neil. 1992. Lotman's Semiosphere. Irish Slavonic Studies 13: 163-167.

Danow, David K. 1991. The Thought of Mikhail Bakhtin. From Word to Culture. Houndmills: MacMillan.

Ivanov, Vyatcheslav Vs. 1998. Izbrannye trudy po semiotike i istorii kul'tury. Vol. 1. Moskva: Jazyki russkoj kul'tury.

Jakobson, Roman 1971. Language in relation to other communication systems. In: Jakobson, Roman, Selected Writings. Vol. 2. The Hague: Mouton, 697-708.

- 1985. Metalanguage as a linguistic problem. In: Jakobson, Roman, Selected Writings. Vol. 7. The Hague: Mouton, 113-121.

Lachmann, Renate 1987. Value aspects in Jurij Lotman's semiotics of culture/semiotics of text. Dispositio 12(30/32): 13-33.

Lotman, Juri 1984 = Лотман, Юрий М. О семиосфере. Труды по знаковым системам (Sign Systems Studies) 17: 5-23.

- 1990. Universe of the Mind: A Semiotic Theory of Culture. London: I. B. Tauris.

- 1992 = Лотман, Юрий М. От редколлегии. Труды по знаковым системам (Sign Systems Studies) 25: 3-4.

- 2000 = Лотман, Юрий. О семиосфере. Культура и взрыв. Внутри мыслящих миров. Статьи. Исследования. Заметки. Санкт-Петербург: Искусство-СПБ.

- 2002 = Лотман, Юрий. Статьи по семиотике культуры и искусства. Санкт-Петербург: Академический проект.

Merrell, Floyd 2001. Lotman's semiosphere, Peirce's categories, and cultural forms of life. Sign Systems Studies 29(2): 385-415.

Portis-Winner, Irene 1999. The dynamics of semiotics of culture; its pertinence to anthropology. Sign Systems Studies 27: 24-45.

- 2002. Semiotics of Peasants in Transition. Slovene Villagers and Their Ethnic Relatives in America. Durham: Duke University Press.

2 The support of Estonian SF grant no. 5313 is acknowledged. 
Shukman, Ann 1989. Semiotics of culture and the influence of M. M. Bakhtin. In: Eimermacher, Karl; Grzybek, P.; Witte, G. (eds.), Issues in Slavic Literary and Cultural Theory. Bochum: Universitätsverlag Dr. Norbert Brockmeyer, 193-207.

Theses 1998 [1973] = Theses on the Semiotic Study of Cultures. (Tartu Semiotics Library 1.) Tartu: Tartu University Press,.

Torop, Peeter 1995-1996. = Тороп, Пеэтер. Статус Тынянова. In: Cедьмые тыняновские чтения. Материаль для обсуждения. Рига: Москва, 49-58.

- 1997 = Тороп, Пеэтер. Достоевский: история и идеология. Tartu: Tartu University Press.

- 2000. New Tartu Semiotics. S: European Journal for Semiotic Studies 2(1): $5-22$.

- 2002. Translation as translating as culture. Sign Systems Studies 30(2): 593605.

- 2003. Semiospherical understanding: Textuality. Sign Systems Studies 31(2): 323-329.

Tynianov, Juri 1977. = Тынянов, Юрий. Поэтика. История литературы. Кино. Москва: Наука.

Żyłko, Bogusław 2001. Culture and semiotics: Notes on Lotman's conception of culture. New Literary History 32(2): 391-408.

\section{Семиосфера и/как объект исследования семиотики культуры}

С 1984 года, когда была напечатана статья Ю. М. Лотмана, данное понятие кочевало из одного терминологического поля в другое. В терминологическом поле семиотики культуры тартуско-московской школы семиосфера связана с понятиями язык - вторичная моделирующая система - текст - культура. Из интердисциплинарных терминологических полей можно считать наиболее существенным примыкание к понятиям биосферы и ноосферы, с одной стороны, и логосферы, - с другой стороны. В качестве метадисциплинарного понятия семиосфера входит в методологию культурологии и связывается с понятием целостности, а также части и целого. В качестве трансдисциплинарного термина семиосфера примыкает к понятию символа в символизме: символ как неопределяемое понятие подходит для передачи познания непознаваемого и в то же время символ может быть семантически насыщенным как редуцированный миф. В данном контексте семиосфера обозначает дополнительность дисциплин, изучающих культуру, и движение в сторону создания общей культурологии и “понимающей методологии”.

Рассуждая о семиосфере на фоне развития современной науки следует помнить, что мы имеем дело одновременно как объектным так 
и метапонятием. Семиосфера - это то, что изучается в культуре или в качестве культуры, и семиосфера является средством для изучения культуры. При помощи семиосферы изучается семиосфера - это не парадокс, а обозначение диалога между объектом исследования и языком его описания. Динамика культуры как объекта исследования заставляет науки искать новые языки описания, но и новые языки описания в свою очередь влияют на динамику развития культуры, так как предлагают новые возможности для самоописания. С исторической точки зрения ноый язык описания часто является лишь методологическим переводом. Так в понятии семиосферы объединены несколько разных концепций, связанных с семиотикой культуры и актуализованных в связи с динамикой развития культуры.

Понятие семиосферы сопоставляет семиотику культуры с ее историей, а также сопрягает прикладной анализ культуры с историей культуры и новейшими явлениями в культуре. От этих сопоставлений зависит место семиотики культуры среди изучающих культуру наук.

\section{Semiosfäär ja/kui kultuurisemiootika uurimisobjekt}

1984. aastast, mil ilmus J. Lotmani artikkel "Semiosfäärist", on see mõiste liikunud ühest terminiväljast teise. Tartu-Moskva koolkonna kultuurisemiootika distsiplinaarsel terminiväljal on ta seotud mõistetega keel — sekundaarne modelleeriv süsteem - tekst — kultuur. Interdistsiplinaarsetest terminiväljadest on ehk olulisem seotus mõistetega biosfäär ja noosfäär ühelt poolt ning logosfäär teiselt poolt. Metadistsiplinaarsena on semiosfäär kultuuriteaduse metodoloogiasse kuuluv mõiste ning seostub seal holismi ning osa ja terviku mõistega. Ja transdistsiplinaarsena on semiosfääri mõiste väga lähedane sümboli mõistele sümbolismis: sümbol on defineerimatu mõistena sobiv tunnetamatu tunnetamise vahendamiseks, samas võib sümbol olla erakordselt suure tähendusmahuga kui redutseeritud müüt. Selles kontekstis tähistab semiosfäär kultuuri uurivate distsipliinide komplementaarsust, liikumist üldise kultuuriteaduse ja "mõistva metodoloogia" loomise suunas.

Semiosfäärist tänapäeva teaduse suundumuste taustal rääkides tuleb meeles pidada, et tegemist on üheaegselt objekt- ja metamõistega. Semiosfäär on see, mida uuritakse kultuuris või kultuurina, ning semiosfäär on see vahend, mille abil kultuuri uuritakse. Semiosfääri abil uuritakse semiosfääri ei ole paradoks, vaid tähistab uurimisobjekti ja tema kirjelduskeele dialoogi. Kultuuri kui uurimisobjekti dünaamika sunnib teadust 
otsima uusi kirjelduskeeli, kuid ka uued kirjelduskeeled mõjutavad omakorda kultuuridünaamikat, sest pakuvad uusi võimalusi enesekirjeldusteks. Tihti on aga uus kirjelduskeel ajaloolisest vaatepunktist vaid metodoloogiline tõlge. Nii ühineb ka semiosfääri mõistes mitu erinevat kultuurisemiootikaga seotud kontseptsiooni, mis on kultuuri arengudünaamika taustal uutmoodi aktualiseerunud.

Semiosfääri mõiste viib kultuurisemiootika uuesti kokku oma ajalooga, nagu ta viib ka rakendusliku kultuurianalüüsi kokku korraga kultuurilooga ja kõige uuemate nähtustega kultuuris. Need kokkupuuted määravad ära kultuurisemiootika koha kultuuri uurivate teaduste seas. 